\title{
Safety Practices and Knowledge of Construction Workers on Hazards Associated with Working on Road Construction Sites in Egor Local Government Area of Edo State
}

\author{
Rotifa Stella, Eguvbe Anthony Okeoghene* \\ Department of Community Medicine, Federal Medical Centre, Yenagoa, Bayelsa State, Nigeria \\ *Corresponding author: doceguvbe@yahoo.com
}

\begin{abstract}
Background: The construction industry is considered as one of the most hazardous industrial sectors in many parts of the world wherein the construction workers are more prone to accidents. Statistics maintained by the Health and Safety Authority (HSA), illustrate that the Construction Industry has a consistently poor record on workers health, safety and welfare relative to other industries. The construction industry is faced with unique safety and health problems that require special attention especially in a developing country like Nigeria. There is little or no data available on morbidity and work- related injuries and associated factors among road construction workers, and in the academic circle, few studies have been conducted among road construction workers. Objectives: To assess safety practices and knowledge of construction workers on hazards associated with working on road construction sites. Methods: A cross-sectional descriptive study was done amongst all construction site workers and their supervisors involved in road construction that have spent at least 6momths on the job in Egor LGA, Edo State. A one stage cluster sampling technique was used to select the study population. Data were collected using a structure questionnaire and were analyzed using SPSS version 16. Results: Majority of the respondents 204(94.9\%) had good knowledge of road construction site hazards. Age and duration of employment was not found to statistically, significantly influence knowledge in this study. However, educational level and hours of work per week greater than 48 hours were both found to influence respondents' knowledge of road construction site hazards positively. Conclusion: The study showed that road construction workers in Egor local government area of Edo state had good knowledge of road construction site hazards, although their knowledge did not translate to regular use of their safety devices. The study shows obvious need for thorough orientation, training and education of construction site workers in Egor LGA.
\end{abstract}

Keywords: safety practices, workers, knowledge, hazards, construction sites

Cite This Article: Rotifa Stella, and Eguvbe Anthony Okeoghene, "Safety Practices and Knowledge of Construction Workers on Hazards Associated with Working on Road Construction Sites in Egor Local Government Area of Edo State.” World Journal of Preventive Medicine, vol. 5, no. 1 (2017): 19-25. doi: 10.12691/jpm-5-1-3.

\section{Background}

Certain workplaces are more hazardous than others owing to exposure, working environment, and the attitude of the workers to preventative measures. The construction industry is considered as one of the most hazardous industrial sectors in many parts of the world wherein the construction workers are more prone to accidents. Statistics maintained by the Health and Safety Authority (HSA), illustrate that the Construction Industry has a consistently poor record on workers health, safety and welfare relative to other industries. Construction activities are typically labour intensive and high risk. [1]

The construction industry is not only the process of building. It involves many other types of work aside from the building process, such as painting, landscaping, electrical supply, telecommunications, plastering, and paving. All these types of work make up one industry, but each of them involves different exposure and thus differing health hazards. Two broad categories of construction projects are building and civil engineering. Building applies to projects involving houses, offices, shops, factories, schools, hospitals, power plants, railway stations, and so on. Civil engineering applies to all the other built structures in our environment, including roads, tunnels, bridges, railways, dams, canals, and docks. In addition, there are structures that appear to fall into both categories - for instance, an airport involves extensive buildings, as well as civil engineering in the creation of the airfield proper and a dock may involve warehouse buildings, as well as excavation of the dock and erection of the dock walls [2]. 
A construction site is a very dangerous environment if safety rules are not followed. An employee who is injured on the work site will claim worker's compensation and drive the rates up for the employer. This also puts pressure on the other workers to complete a job with one less employee, and the same pressure is conveyed to the company in order to reach completion deadlines. Accidents in the construction site due to poor safety practices is a loss for both the employer and the employee, and are best avoided by observing the use of common safety practices. [3]

The International Labour Organisation (ILO) estimates at least 60,000 fatal accidents a year on construction sites around the world, that is one in six of all fatal workrelated accidents. [4] The global trade union federation puts the figure much higher at 108,000 with construction responsible for $30 \%$ of all work related accidents. While securing a job in construction offers a potential route out of poverty for many of the world's poorest, subsequent inability to work due to injury or ill-health can drive these workers families into destitution. The causes of accidents and injuries that occur in construction are foreseeable and preventable. [5] In the developing world, there is a risk associated with construction work. United State Bureau of Labor Statistics (BLS) data show that, in 2003, construction workers were $7 \%$ of the U.S. workforce, but suffered $21 \%$ of the nation's 5,575 reported work-related deaths. That same year, nonfatal rates of injury and illness involving days away from construction work were 259.4 per 10,000 fulltime equivalents (FTEs),1 higher than for agriculture, mining, and manufacturing. [6] In Egypt, 18 per cent of occupational injuries were recorded among workers in the construction industry. [7] Apart from the actual costs incurred regarding injuries and fatalities, the national economy of any country suffers enormous cost and loss of productivity as a consequence of occupational injuries and even deaths.

A cross sectional study carried out in north central Nigeria to determine the level of awareness of Occupational Hazards, and Safety Measures among machine operators and sawmill workers showed that the most perceived occupational hazards in the sawmill were dust and noise among $28.1 \%$ of sawmill workers and $26.1 \%$ machines operators respectively. Less than $20 \%$ of the sawmill workers wore protective devices/clothing, and health and safety standards were neither practiced nor enforced. The study concluded that the level of awareness of various occupational hazards was low except that of electric shock that was high. The most common health problems experienced was minor accidents. Availability and use of safety devices were also poor. Socio-demographic factors were not found to influence the attitude and use of safety measures at workplace but awareness had significant influence on the level of use of safety measures. [8]

Similarly, a cross sectional study was conducted to assess the knowledge, attitude and practice of occupational health problems among salt workers working in the desert of Rajasthan, India. The sample consisted of 205 salt workers. Data was collected using interview technique. Workers were interviewed about health hazards and problems related to their working conditions, usage of protective measures and suggestions for their improvisation. The brine workers had a fair knowledge of their occupational health problems (98.7\%), protective measures (100.0\%) and their benefits (100.0\%) as compared to non brine workers for whom these figures were $89.0 \%, 85.8 \%$ and $78.7 \%$ respectively. The brine workers $(29.5 \%)$ and non brine workers (31.5\%) used unconventional measures to prevent contact with salty water, salt dust, raw salt and glare. There was a huge gap between their knowledge and practice with usage of protective devices. The study concluded that improvements in protective devices are needed to increase their acceptability. [9]

Another cross-sectional study was carried out on workers in MahshahrRazy Petrochemical Complex in Iran. The aim was to determine the level of knowledge, attitude and behavior of Workers towards occupational health and safety. A sample size of 210 participants was randomly selected. Data collection tool was via a questionnaire. The results showed that the mean age of the workers was 31.1 years. The mean of their knowledge, attitude and behavior was reported as 26.02, 153.18and 36, respectively. 52.9\% of workers had low, $36.7 \%$ moderate and $10.5 \%$ high level of knowledge. In addition, $75.7 \%$ of the participants had a positive attitude towards occupational health and safety; $30 \%$ of workers had low safety behavior and $70 \%$ had safe behavior. The mean of knowledge grade shows a significant relationship with education level. A same relationship was reported for the mean of attitudes and behavior with age. The study concluded that managers should design and implement educational interventions to promote knowledge, attitude and safe behaviors of workers. [10]

\section{Methods}

The study was conducted in Egor, one of 3 local government areas that make up the metropolitan city of Benin, the capital of Edo state, Nigeria. It is situated in the tropical rain forest belt at 122 metres above sea level, bounded on the north and east by Ovia north-east, on the south by Oredo and Ikpobha-Okha and on the east by Uhunmwodu. The total population of Egor local government area stands at 339,899 (males 168,029 and females 171,870). [11] Christianity, Islam and Traditional African religion are the most common religions. Majority of the dwellers are of Benin tribe, the others are non indigenes. Egor Local Government Area has both public and private health facilities ranging the three tiers of primary, secondary and tertiary health care. It has a number of educational institutions, religious institutions and other social amenities.

There is the presence of a number of construction industries particularly involved in road construction. These include: Servetek Construction Company, with its head office at Airport road, and branch office at UgbowoLagos road Benin-city. Setraco Construction Company with its head office at the Government Reservation Area, off Sapele road, Benin-city. Hi-Tech Construction Company, off Textile mill road, Benin-city, GMAN Construction Company along New Lagos road Benin-city.

There was also the presence of various other industries such as agro-allied industries, bottling, woodwork and numerous small scale industries.

The study was a cross-sectional descriptive study amongst all construction site workers and their supervisors 
involved in road construction that have spent at least 6 momths on the job. A duration of at least 6 months from date of employment will allow for the assumption that the worker would have received some safety training and supervision if available in the industry within that period.

The minimum sample size for the study was calculated using the Cochran formula for minimum sample size determination in a descriptive, cross-sectional study. [12]

$$
\mathrm{n}=\frac{\mathrm{z}^{2} \mathrm{pq}}{\mathrm{d}^{2}}
$$

Where

$\mathrm{n}=$ the desired sample size

$\mathrm{p}=$ the population in the target population estimated to have a particular characteristic.

$\mathrm{q}=1.00-\mathrm{p}$.

$\mathrm{d}=$ degree of accuracy required, usually set at $5 \%$.

$\mathrm{z}=$ the standard normal deviate to be used for the study is set at 1.96 which corresponds to the $95 \%$ confidence level.

Therefore, using $\mathrm{p}=9.6 \%=0.096$ (prevalence of cuts among construction workers in Thailand [19]), $\mathrm{E}=5 \%$,

$$
\begin{gathered}
\mathrm{q}=1-\mathrm{p}=90.4=0.904 \\
\mathrm{n}=\frac{1.96^{2}(0.096 \times 0.904)}{0.05^{2}} \\
\mathrm{n}=133.4
\end{gathered}
$$

Approximately $\mathrm{n}=133.4$

Allowing for a $10 \%$ non response rate $=13.3$

Therefore $n=133.4+13.3=146.7=147$.

However, to enhance validity, total population of the construction workers at the road construction sites was used.

A one stage cluster sampling technique was used to select the study population. A list of on-going road construction sites and the construction companies in charge was obtained. There were five construction companies viz; Setraco, Servetek, Hi-tech, GMN and RCC and six on-going road construction work at the time of this study. Each construction site was taken as a cluster. A preliminary survey was done to determine the number of construction workers in each construction site. The number of construction clusters needed to yield the sample size was calculated to be 4 . However, 5 out the 6 on-going construction sites were studied. A total population of eligible road construction workers found at these construction sites was studied.

A structured questionnaire which consist of both open and closed ended questions were administered by 2 trained research assistants. The research assistants were trained for three days on the proper use of the research tools. The questionnaire was divided into sections and information was sought on the socio-demographic and occupational characteristics of respondents; Knowledge of road construction site hazards; Availability of safety rules and measures on construction sites; and utilization of safety devices.

A pre-test of the questionnaire was carried out in 2 construction sites in Sapele, the headquaters of Sapele Local Government, Delta state, with 50 participants to enhance comprehensibility, validity, reliability and sensitivity of questions, and for average duration of administration.
Corrections to the questionnaire were effected prior to the commencement of the study.

An observational checklist was used to do a Walkthrough survey and direct observation of the work environment and availability of safety devices on the construction sites with the assistance of the various site safety officers. The distribution of the construction sites were as follows: Site A: Setraco construction company; Site B: Servetek construction company; Site C: Hi -Tech construction company; Site D: GMAN construction company.

The filled questionnaires were screened for completeness by the researcher, coded and entered into the Statistical packages for social sciences (SPSS) version 16.0 software for analysis. The mean, standard deviation and proportion of the variables was calculated. Statistical test of association and test of significance was carried out where applicable. The level of significance is set at $\mathrm{p}<0.050$. The data is presented in statements, frequency distribution tables, cross-tables and figures.

For the purpose of this study, respondents' knowledge of road construction site hazards based on information obtained from existing literature, was scored using a scoring system designed by the researcher to enable further analysis and interpretation. Details of the contextual assignment of scores are explained below:

Scoring of knowledge of road construction site hazards was assessed by awarding points to answers given for a set of 10 questions related to the topic in the questionnaire. For each of the question, respondents who answered "Yes" were scored 1, those who indicated "No" and "I do not know" were scored 0.

Based on the assigned scores above, maximum composite score for knowledge of road construction site hazards was 10 while the least score was 0 . Therefore, respondents with scores $0-4$, were categorized as having poor $(<50 \%)$, and good $(\geq 50 \%)$ overall knowledge of road construction site hazard respectively.

Approval to conduct this research was sought and obtained from the department of Community Health of the University of Benin. Verbal permission was sought from the management of the construction companies. Informed written consent was obtained from each respondent before conducting interviews after adequate information had been given to them by the interviewers. Privacy of the respondents was respected during the interviews. Respondents were informed that they had the right to decline participation or to withdraw from the study at any time they wished. Respondents were also informed that there were no penalties or loss of benefits for refusal to participate in the study or withdraw from it. There were no risks of harm or injury to the participants during and after the conduct of the study.

All data were kept secure and made available only to the researcher. Health education was given on a group basis to the workers at the construction sites on the importance of safety and the need to abide by safety rules.

\section{Results}

The mean age (SD) of the respondents was 33 (9) years. About 200 (93\%) of the respondents were males while 15 
(7\%) were females. Majority of the respondents 117(54.4\%) were married, 97(45.1\%) were single and 1 (0.5\%) was divorced. About 111 (51.6\%) had secondary education, 65 (30.2\%) had tertiary education, 31(14.4\%) had primary education while $8(3.7 \%)$ had no education. Majority of the respondents were Binis 72 (33.5\%) and Esan 36(16.7).

Table 1. Socio-demographic characteristics of the respondents

\begin{tabular}{lcc}
\hline Variable & Frequency & Percentage (\%) \\
\hline Age group (years) & 71 & 33.0 \\
$18-27$ & 92 & 42.8 \\
$28-37$ & 40 & 18.6 \\
$38-47$ & 12 & 5.6 \\
48 and above & & \\
Sex & 200 & 93.0 \\
Male & 15 & 7.0 \\
Female & & \\
Marital status & 97 & 45.1 \\
Single & 117 & 54.4 \\
Married & 1 & 0.5 \\
Divorced & & \\
Level of Education & 8 & 3.7 \\
None & 31 & 14.4 \\
Primary & 111 & 51.6 \\
Secondary & 65 & 30.2 \\
Tertiary & & \\
Ethnicity & 72 & 33.5 \\
Bini & 36 & 16.7 \\
Esan & 33 & 15.3 \\
Yoruba & 28 & 13.0 \\
Ibo & 18 & 8.4 \\
Urhobo & 14 & 6.5 \\
Hausa & 10 & 4.6 \\
Ibibio & 7 & 3.3 \\
$*$ Others & & \\
\hline
\end{tabular}

*Others included Ijaws and Ashanti(Ghana).

Figure 1 shows the religion of the respondents. A higher percentage of the respondents (83.3\%) were Christians, $15.3 \%$ were Muslims and $1.4 \%$ African traditional religion.
In Table 2, respondents who had spent between 1 and 5 years in employment made up the greater proportion in the study (67.0\%), Respondents who had spent more than 5 years in employment made up the smallest proportion: $8(3.7 \%)$. The mean duration of work (SD) was $2.49 \pm(2)$.

The mean hours worked per week (SD) was $49 \pm(13)$ hours. About $43(20 \%)$ of the respondents were masons, $32(14.9 \%)$ were laborers, $21(9.3 \%)$ were safety officers and $16(7.4 \%)$ were site engineers.

Table 2. Occupational characteristics of the respondents

\begin{tabular}{lcl}
\hline Variable & Frequency & Percentage (\%) \\
\hline $\begin{array}{l}\text { Duration of work (years) } \\
<1\end{array}$ & 63 & \\
$1-5$ & 144 & 67.3 \\
$>5$ & 8 & 3.7 \\
Mean duration of work \pm SD & $2.49 \pm 1.51$ & \\
\hline Hours worked per week & & \\
$\leq 24$ & 5 & 2.3 \\
$25-48$ & 94 & 43.7 \\
$>48$ & 116 & 54.0
\end{tabular}

Mean hours worked \pm SD $=49 \pm 13.29$

\begin{tabular}{lll}
\hline Designation & 43 & 20.0 \\
Masons & 32 & 14.9 \\
Labourers & 21 & 9.3 \\
Iron benders & 20 & 9.3 \\
Safety officers & 20 & 9.3 \\
Excavator officers & 16 & 7.4 \\
Site engineers & 14 & 6.5 \\
Electricians & 13 & 6.0 \\
Mechanics & 10 & 4.7 \\
Carpenters & 8 & 3.7 \\
Flagmen & 5 & 2.3 \\
Quantity surveyors & 3 & 1.4 \\
Site nurse & 5 & 2.3 \\
Driver & 6 & 2.8 \\
Others &
\end{tabular}

**Others included fuel clerk, site security officers and time keepers.

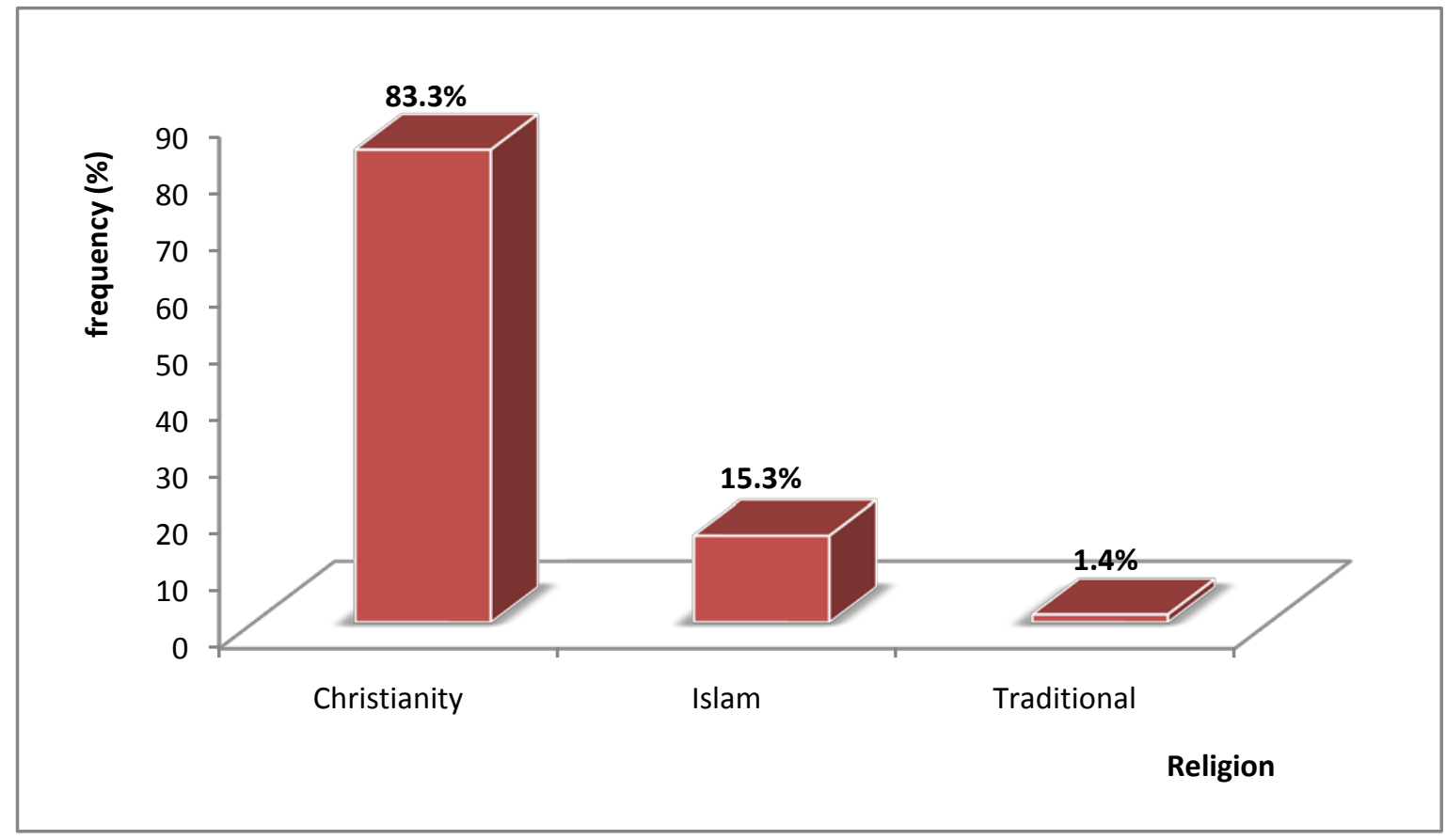

Figure 1. Religion of respondents 


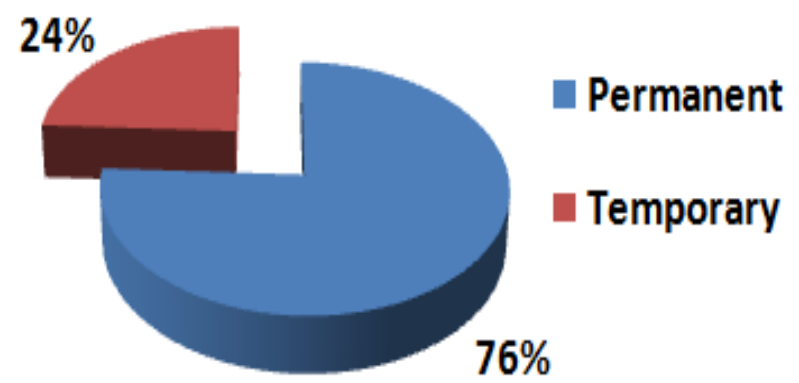

Figure 2. Type of employment of respondents

About $76 \%$ of the respondents were permanent employees while $24 \%$ were temporary employees.

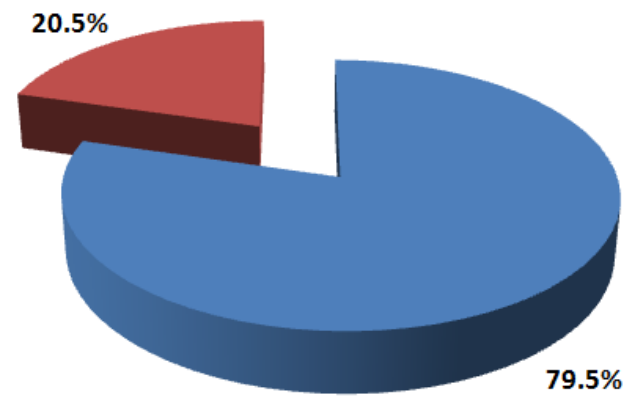

naywork Ehiftwork

Figure 3. Work schedule of respondents

About $79.5 \%$ of the respondents were on day work (6am-6pm) while $20.5 \%$ of the respondents were on shift work.

Table 3. Knowledge of road construction site hazards among respondents

\begin{tabular}{lcc}
\hline Knowledge & Frequency & Percentage (\%) \\
\hline Good knowledge & 204 & 94.9 \\
Poor knowledge & 11 & 5.1 \\
\hline Total & 215 & 100.0 \\
\hline
\end{tabular}

The knowledge of road construction site hazards among respondents. Majority of the respondents 204(94.9\%) had good knowledge while 11(5.1\%) had poor knowledge of road construction site hazard.

Table 4. Age of respondents and knowledge of construction site hazards

\begin{tabular}{cccc}
\hline \multirow{2}{*}{ Age group (years) } & \multicolumn{2}{c}{ Knowledge (\%) } & \multirow{2}{*}{ Total (\%) } \\
\cline { 2 - 3 } & Good & Poor & \\
\hline $18-27$ & $67(32.8)$ & $4(36.4)$ & $71(33.0)$ \\
$28-37$ & $86(42.2)$ & $6(54.5)$ & $92(42.8)$ \\
$\geq 38$ & $51(25.0)$ & $1(9.1)$ & $52(24.2)$ \\
\hline Total & $\mathbf{2 0 4}(\mathbf{1 0 0 . 0 )}$ & $\mathbf{1 1 ( 1 0 0 . 0 )}$ & $\mathbf{2 1 5 ( 1 0 0 . 0 )}$ \\
\hline
\end{tabular}

FISHER'S EXACT TEST, $\mathrm{p}=0.536$.

Among the respondents that had good knowledge, $86(42.2 \%)$ were in the $28-37$ age group, 67(32.8\%) were in the 18-27 age group and 51 (25\%) were 38years and above. When compared with those with poor knowledge, the difference was not statistically significant (FISHER'S EXACT TEST, $\mathrm{p}=0.536$ ).
Table 5. Level of education of respondents and knowledge of road construction site hazards

\begin{tabular}{|c|c|c|c|}
\hline \multirow{2}{*}{ Level of education } & \multicolumn{2}{|c|}{ Knowledge (\%) } & \multirow{2}{*}{ Total (\%) } \\
\hline & Good & Poor & \\
\hline None & 8 (3.9) & $0(0.0)$ & $8(3.7)$ \\
\hline Primary & $27(13.2)$ & $4(36.4)$ & $31(14.4)$ \\
\hline Secondary & 108 (52.9) & $3(27.3)$ & $111(51.6)$ \\
\hline Tertiary & 61 (29.9) & $4(36.4)$ & $65(30.2)$ \\
\hline Total & 204 (100.0) & $11(100.0)$ & $215(100.0)$ \\
\hline
\end{tabular}

FISHER'S EXACT TEST, $\mathrm{p}=0.137$.

Table 5 shows level of education of respondents and their knowledge of road construction site hazards. Majority of respondents with good knowledge of road construction site hazards $108(52.9 \%)$ had secondary education. About $61(29.9 \%)$ of the respondents with good knowledge had tertiary education, $27(13.2 \%)$ had primary education while $8(3.9 \%)$ had no education. This difference in level of education and knowledge of road construction hazards was not found to be statistically significant $\mathrm{p}=0.137$.

Table 6. Duration of employment and knowledge of road construction site hazards

\begin{tabular}{cccc}
\hline \multirow{2}{*}{$\begin{array}{c}\text { Duration of } \\
\text { employment (years) }\end{array}$} & \multicolumn{2}{c}{ Knowledge (\%) } & \multirow{2}{*}{ Total (\%) } \\
\cline { 2 - 3 } & Good & Poor & \\
\hline 1 & $60(29.4)$ & $3(27.3)$ & $63(29.3)$ \\
$1-5$ & $136(66.7)$ & $8(72.7)$ & $144(67.0)$ \\
$>5$ & $8(3.9)$ & $0(0.0)$ & $8(3.7)$ \\
\hline Total & $\mathbf{2 0 4 ( 1 0 0 . 0 )}$ & $\mathbf{1 1 ( 1 0 0 . 0 )}$ & $\mathbf{2 1 5 ( 1 0 0 . 0 )}$ \\
\hline
\end{tabular}

FISHER'S EXACT TEST, $\mathrm{p}=1.000$.

Table 6 shows the association between the duration of employment and knowledge of road construction site hazards. About 136 (66.7\%) of respondents with good knowledge of road construction hazards had worked in the industry for between 1 and 5 years. All the respondents who had worked for greater than 5years also had good knowledge. The difference was not statistically significant. $\mathrm{p}=1.000$

Table 7. Hours worked per week and knowledge of road construction hazards

\begin{tabular}{cccc}
\hline \multirow{2}{*}{ Hours worked per week } & \multicolumn{2}{c}{ Knowledge (\%) } & \multirow{2}{*}{ Total (\%) } \\
\cline { 2 - 3 } & Good & Poor & \\
\hline $24-48$ & $98(48.0)$ & $1(9.1)$ & $99(46.0)$ \\
$>48$ & $106(52.0)$ & $10(90.9)$ & $116(54.0)$ \\
\hline Total & $\mathbf{2 0 4 ( 1 0 0 ’ 0 )}$ & $\mathbf{1 1 ( 1 0 0 ’ 0 )}$ & $\mathbf{2 1 5 ( 1 0 0 . 0 )}$ \\
\hline
\end{tabular}

FISHER'S EXACT TEST, p = 0.012 .

Table 7 shows the association between the hours worked per week of respondents and the knowledge of road construction site hazards. Majority of respondents 106(52\%) who worked for greater than 48 hours per week had good knowledge of road construction site hazards. This difference was found to be statistically significant. $\mathrm{p}=0.012$. 


\section{Discussion}

Majority of the respondents in this study (42.8\%) were within the age group of 28-37 years with a mean age of 32.9 \pm 9(s). This finding was consistent with similar studies conducted in Iran [10] and Saudi-Arabia. [13] This represents a relatively young workforce and may be attributable to the fact that road construction is a laborious job, requiring people who are still strong and active. In this study, respondents that had completed secondary level of education made the largest percentage of $51.2 \%$ while those with those with tertiary education constituted about $30.6 \%$. An earlier study among sawmill workers in the south-western states in Nigeria documents a similar finding. [14] However, this is at variance with study among construction workers in Thailand [15] where majority of the respondents (86.6\%) attained primary level of education.

In this study, a greater proportion of respondents had spent between 1 and 5 years in employment, with mean duration of employment as 2.5(1.5) years. This finding is similar to what was obtained in Al-khobar Saudi-Arabia [14] and lower than what was reported in a study in Thailand, [16] where mean duration of employment was found to be 4 years. This may be because the construction work force is a highly mobile one, and workers turnover rates are relatively high. It may also be due to "healthy worker effect"; a situation where workers who had been injured were more likely to have left the workplace, leaving those relatively healthy.

A greater proportion of the construction workers (54\%) worked for longer than 48 hours a week, a practice outside that recommended by the 1974 labour decree in Nigeria, [17] and the 1935 International Labour Organization forty hour week convention. [18]

This finding may be as a result of construction workers working evenings, weekends and holidays to finish a job or take care of an emergency. It may also be as a result of the weak enforcement of labour laws in the country, ignorance of the law among workers, as well as the high level of unemployment in the country that leaves the worker desperate for employment and at the mercy of his employer

Knowledge of road construction hazards was found to be good (94.9\%) among the construction workers in this study. This finding is similar to what was obtained in a study carried out in of Rajasthan, India [9] among brine workers where knowledge of occupational hazards was found to be good (98.7\%). It is important to point out that differences in criteria used to assess knowledge might have also contributed to this finding. There was good of knowledge of road construction hazards among the respondents, however, it was not significantly associated with the age of the respondents or their level of education. This is at variance with the study on occupational hazard and safety carried among petrochemical workers in Iran [19] where knowledge of occupational hazard and safety was significantly associated with the level of education of the workers. However, in this study knowledge of construction hazards was significantly associated with hours worked per week. Majority of respondents (52\%) who worked for greater than 48 hours per week had good knowledge of road construction hazards. This could be as a result of prolonged exposure to the work environment which made the worker more familiar with the hazards on the work sites.

\section{Conclusion}

The study showed that road construction workers in Egor local government area of Edo state had good knowledge of road construction hazards, although their knowledge did not translate to regular use of their safety devices. Increasing level of education was associated with regular use of the safety devices. We recommend to managers of construction companies the need to train and educate its employees to follow safe methods of work and take a sincere interest in the safety of themselves and their fellow workers.

\section{References}

[1] RIA - Safety, Health and Welfare at Work (Construction) Regulations 2006.

[2] Hinksman J. Construction, major sectors. In: Jean MagerStellman et al., eds. Encyclopaedia of occupational health and safety. 4th edition ILO, Geneva, 1998; 3:93.1.

[3] Occupational Safety \& Health Administration (OSHA) www.osha.gov.

[4] BLS, Bureau of Labor Statistics, U.S. Department of Labor. 2003. Washington, DC. Accessed on July 29th 2010 at http://www.bls.gov/iif/home.htm.

[5] Estimate by ILO on the occasion of the World Day for Safety and health at Work, 2005Accessed on July 29th 2010 at. http://www.ilo.org/global/About the ILO/Media and public information/Press_releases/langen/WCMS 005161/index.htm.

[6] Eurostat, ESAW 1999.

[7] Ale, B.J.M.; Bellamy, L.J.; Baksteen, H.; Damen, M.; Goossens, L.H.J.; Hale, A.R.; Mud, M.; Papazoglou OH, Whiston, J.Y. Accidents in the construction industry in the Netherlands: An analysis of accident reports using Story builder. Reliability Engineering \& System Safety. 2008; 93(10): 1523-1533.

[8] Osagbemi G K, La-Kadri R T, Aderibigbe S A.Awareness of occupational hazards, health problems and safety measures among sawmill workers in North Central Nigeria. TAF Prev Med Bull 2010; 9(4): 325-328.

[9] Haldiya KR, Sachdev R, Mathur ML, Saiyed HN. Knowledge, attitude and practices related to occupational health problems among salt workers working inthe desert of Rajasthan, India. J Occup Health 2005 Jan; 47(1): 85-8.

[10] Sanaei H, Ghofranipour F, Kazemnejad A, Khavanin A, Tavakoli R. Evaluation of Knowledge, Attitude and Behavior of Workers towards Occupational Health and Safety. Iranian J Publ Health. 2009; 38(2): 125-129.

[11] National Population Commission of Nigeria. 2006 Population and Housing Census Facts and Figures. [Cited 2008 November 6]. Available from: http://www.population.gov.ng/factssand figures2006.

[12] Cochran G. Sampling Techniques, $2^{\text {nd }}$ ed. New York: John Wiley and Sons, Inc. 1963.

[13] Parimalam P, Kamalamma N, Ganguli AK. . Knowledge, attitude and practices related to occupational health problems among garment workers in Tamil Nadu, India. J Occup Health. 2007; 49(6): 528-34.

[14] Taha AZ. Knowledge and practice of preventive measures in small Industries in Al-Khobar. Saudi Med J 2000 Aug; 21(8): 740-5.

[15] Chongsuvivatwong V, Pas-ong S, Ritsmithchai S, lebel L, Pkamolrattanakul K, Dhanamun B, et al. A Multi-Centre CrossSectional Survey onSafety at Construction Sites in Thailand. J Occup Health 1998; 40: 319-324.

[16] Aaltonen MV. Occupational injuries in the Finnish furniture industry. ScandJWork Environ Health 1996 Jun; 22(3): 197-203. 
[17] Encyclopedia of the nations. Nigeria working conditions. [Cited 2010 April 11]. Available from:

http://www.nationsencyclopedia.com/.../Nigeria.

[18] Convention CO47-Forty-Hour Week Convention, 1935 (No. 47). Accessed at www.ilo.org/dyn/normlex/en.
[19] Bushra I, Hamid H, Saatea A, Ghulam S. The frequency of occupational injuries and injury-related life style indicators in industrial workers of Peshawar. J. Med. Sci. (Peshawar, Print) Jan 2009; 17(1): 35-39. 